\title{
PERAN DIPLOMASI PUBLIK DALAM MEMPERKUAT HUBUNGAN BILATERAL INDONESIA - AMERIKA SERIKAT PADA MASA PEMERINTAHAN SUSILO BAMBANG YUDHOYONO (2004 - 2014)
}

\author{
Dina Puspita S. Pelenkahu
}

\begin{abstract}
Public Diplomacy as a part of soft power has been the main principle of Indonesia's diplomacy under President Yudhoyono. Due to the ineffectiveness of Track 1 Diplomacy, Government-to-Government (G2G) relations, in promoting the positive image of Indonesia, the role of public diplomacy becomes important. Thus, public diplomacy practice which involves all aspects of society; Government to Government (G2G), Government to People Contact (G2P), and People to People Contact (P2P), is relevant in order to promote Indonesia to American society and strengthening its bilateral relations as well. This research, therefore, is trying to discuss the role of public diplomacy in strengthening the RI-US bilateral relations and its benefits to Indonesia's foreign policy. The findings show that public diplomacy contributes in strengthening RI-US bilateral relations by the use of public diplomacy instruments such as cultural and educational exchanges, official visits and social media.
\end{abstract}

Keywords: Soft Power, Public Diplomacy, RI-US Bilateral Relations.

\section{PENDAHULUAN}

\section{LATAR BELAKANG}

Indonesia, yang menganut prinsip politik luar negeri bebas aktif, terlibat dalam kerjasama-kerjasama bilateral maupun multilateral dengan negara-negara lain di kancah internasional. Keterlibatan Indonesia dalam kerjasama internasional baik bilateral maupun multilateral tersebut tentunya tidak terlepas dari tujuan politik luar negeri Indonesia yang memiliki kepentingan nasional di dalamnya. Dengan demikian, Indonesia dapat mengambil manfaat sebesar-besarnya dari kerjasama yang dilakukan, khususnya ketika kerjasama dilaksanakan dengan negara-negara yang memiliki kemampuan lebih dalam bidang politik, ekonomi ataupun keamanan. Amerika Serikat, dalam konteks ini menjadi salah satu partner penting dalam kerjasama bilateral yang dilakukan Indonesia. Hubungan bilateral Indonesia dan Amerika Serikat telah lama terjalin, bahkan sejak awal kemerdekaan Indonesia pada masa pemerintahan Presiden Soekarno, walaupun dengan adanya pasang surut dalam hubungan bilateral tersebut. Hubungan Indonesia - 
Amerika Serikat dapat dianalogikan seperti "when love and hate collide" dimana hubungan kedua negara ini mengalami pasang surut dan perbedaan yang cukup signifikan pada masa pemerintahan presiden-presiden Indonesia.

Terdapat dua poin utama mengapa Amerika Serikat menjadi penting bagi Indonesia. Pertama, dengan menjaga dan memperkuat hubungan bilateral Indonesia - Amerika Serikat, Indonesia dapat meningkatkan kapasitas sumber daya manusianya. Hal ini dapat dicapai dengan peningkatan mobilitas masyarakat Indonesia ke Amerika dengan tujuan sharing experience and knowledge yang dapat digunakan untuk membangun bangsa. Kedua, Amerika Serikat tidak dipungkiri memiliki peran penting dalam perekonomian global dan percaturan dunia. Jika hubungan bilateral Indonesia-Amerika Serikat terjaga stabilitasnya maka akan berdampak pada peningkatan pembangunan perekonomian Indonesia. Tidak hanya itu, Indonesia juga dapat menjadikan dukungan Amerika Serikat sebagai kesempatan untuk meningkatkan peran sentralnya baik di kancah regional ataupun internasional. Peningkatan hubungan Indonesia dengan Amerika Serikat juga akan berdampak pada peningkatan pembangunan ekonomi, politik, pertahanan dan keamanan, tidak hanya bagi Indonesia, namun juga Amerika Serikat baik pada tingkat regional maupun internasional. Hal ini dikarenakan Indonesia berperan penting dalam geopolitik Asia, Indonesia menjadi pintu masuk Amerika dalam meloloskan kepentingannya di wilayah tersebut. Selain itu Indonesia juga menjadi partner strategis Amerika dalam pemberantasan terorisme. ${ }^{1}$

Pada hakikatnya, alat untuk mencapai tujuan politik luar negeri adalah dengan menggunakan diplomasi. Namun, di era globalisasi ini, dimana mobilitas masyarakat telah semakin tinggi dan kesadaran politik bernegara di seluruh aspek masyarakat juga semakin meningkat, diplomasi yang dilakukan tidak cukup pada diplomasi konvensional. Hal ini dikarenakan diplomasi konvensional tersebut hanya melibatkan aktor pemerintah dan hanya fokus pada relasi government to government. Oleh karena itu, diperlukan strategi

\footnotetext{
${ }^{1}$ Sukma, Rizal. 2010. Insight: Strategic Significance of Indonesia-US Relations. The Jakarta Post 10 November 2010 .
} 
diplomasi yang mampu menginklusi seluruh aspek masyarakat untuk berperan aktif. Disinilah diplomasi publik kemudian mengambil peran. Dengan diplomasi publik relasi antara pemerintah dengan masyarakat dapat lebih terakomodir karena fokus aktivitas diplomasinya adalah pada tataran government to people contact dan people to people contact. Selain itu, perkembangan teknologi informasi di era ini juga menjadi alasan tak terelakkannya keterlibatan masyarakat dalam aktivitas diplomasi. Terlebih dengan perkembangan isu-isu domestik dan internasional yang menuntut pemerintah untuk membuka keterlibatan publik karena pemerintah tidak dapat menyelesaikan seluruh permasalahan dari isu-isu tersebut jika bergerak sendirian.

Diplomasi publik menjadi penting bagi Indonesia dalam peningkatan hubungan bilateral, terhadap Amerika Serikat khususnya, karena dengan diplomasi publik Indonesia dapat memberikan pemahaman mengenai kebijakan luar negeri dan aktivitas-aktivitas politik atau diplomasinya kepada publik domestik ataupun internasional dengan lebih mudah. Hal ini ditunjang dengan diplomasi publik yang menawarkan berbagai instrumen yang dapat digunakan secara efektif dalam upaya mempengaruhi opini publik, baik domestik maupun internasional. Selain itu, diplomasi publik juga dapat membentuk mutual understanding antara publik Amerika Serikat dan Indonesia yang pada akhirnya dapat memberikan dampak pada hubungan bilateral yang lebih terjaga dan pencegahan konflik juga pencapaian kepentingan nasional yang lebih luas. Hal tersebut dapat tercapai karena adanya dukungan dari publik dan citra positif yang telah dibangun yang juga dapat membentuk kepercayaan dalam menjalin kerjasama bilateral yang lebih matang dan komprehensif.

Di masa pemerintahan Presiden Susilo Bambang Yudhoyono, dalam menjalankan politik luar negeri Indonesia pendekatan yang dilakukan menekankan pada pendekatan diplomasi soft power. Presiden Susilo Bambang Yudhoyono menekankan bahwa abad 21 ini adalah abad soft power dimana 


\section{Global Insight Journal}

keutamaan akan kepercayaan dan kerjasama antar negara patut ditingkatkan. ${ }^{2}$ Presiden Susilo Bambang Yudhoyono juga menginstruksikan untuk menekankan soft power dalam bentuk kebudayaan, nilai-nilai, kebijakan, value dan achievement yang telah dicapai oleh bangsa Indonesia. ${ }^{3}$ Hal-hal tersebut dapat berupa kebudayaan Indonesia seperti batik, alat musik dan tarian tradisional, juga ideas seperti Indonesia as a peacekeeper, Indonesia sebagai negara dimana agama dan demokrasi dapat berjalan beriringan dan lain-lain. Diplomasi yang dilakukan melalui hal-hal tersebut sebagai bagian dari diplomasi publik menjadikan soft power sebagai penguat formula diplomasi Indonesia. Dengan kata lain diplomasi publik dapat menjadi penunjang diplomasi yang dilakukan dalam tingkat formal atau first track diplomacy yang pada akhirnya membantu meningkatkan dan menjaga long term relationship dalam hubungan bilateral yang dijalin oleh Indonesia dengan negara lain.

\section{RUMUSAN MASALAH}

Berdasarkan latar belakang yang telah dikemukakan di atas maka rumusan masalah dalam penelitian ini adalah sebagai berikut:

a. Mengapa Indonesia melakukan diplomasi publik secara aktif dalam hubungan bilateralnya dengan Amerika Serikat?

b. Bagaimana diplomasi publik berperan dalam memperkuat hubungan bilateral Indonesia dengan Amerika Serikat?

\section{KERANGKA ANALISIS}

Analisis yang dilakukan dalam penelitian ini menggunakan pendekatan konseptual diplomasi publik dan multi-track diplomacy. Istilah diplomasi publik digunakan pertama kali oleh Dean Edmund Gullion dari Fletcher

\footnotetext{
${ }^{2}$ Pidato Presiden Susilo Bambang Yudhoyono. 2009. Towards Harmony Among Civilizations. John F. Kennedy School Of Government Harvard University: Boston.

http://www.presidenri.go.id/index.php/eng/pidato/2009/09/30/1228.html. Diakses Tanggal 29 Agustus 2014.

${ }^{3}$ Direktorat Diplomasi Publik. 2010. "Presiden RI: Soft Power Memperkuat Formula Diplomasi". Tabloid

Diplomasi No. 28 Tahun III. Direktorat Diplomasi Publik RI: Jakarta.
} 
School of Law Diplomacy, Universitas Tufts, Amerika Serikat Serikat, pada tahun 1965. ${ }^{4}$ Definisi dari diplomasi publik pada dasarnya sangat beragam namun merujuk dari definisi diplomasi publik pada awal kemunculannya dapat dikatakan bahwa diplomasi publik didefinisikan sebagai upaya mencapai kepentingan nasional suatu negara melalui understanding, informing, and influencing foreign audiences. Dengan kata lain, jika proses diplomasi konvensional dikembangkan melalui mekanisme government to government relations, maka diplomasi publik lebih ditekankan pada government to people relations atau people to people relations. Tujuannya adalah agar masyarakat internasional mempunyai persepsi tentang suatu negara, sebagai landasan sosial bagi hubungan dan pencapaian kepentingan politik luar negeri yang lebih luas.

Selain itu, dengan melakukan diplomasi publik, suatu negara dapat mempengaruhi publik domestik ataupun internasional demi mencapai kepentingan atau kebijakan luar negerinya. ${ }^{5}$ Hal ini mengindikasikan bahwa opini publik juga memiliki peran penting dalam membentuk kebijakan luar negeri dan juga pengaplikasian kebijakan tersebut. Dalam melakukan diplomasi publik, terdapat beberapa instrumen yang dapat digunakan, Instrumen-instrumen tersebut dapat berupa publikasi, film, pertukaran budaya, dan media sosial seperti radio dan televisi. Namun pengaplikasian intrumeninstrumen tersebut memerlukan dukungan atau inisatif dari pemerintah. ${ }^{6}$ Jadi dalam konteks ini, peran pemerintah tetap menjadi yang utama dalam aktivitas diplomasi publik. Walaupun pada prakteknya yang melakukan aktivitas diplomasi publik adalah aktor-aktor non pemerintah yang terlibat aktif seperti NGO, individu, atau media (cetak/elektronik), pemerintah tidak boleh lepas pengawasan.

Strategi diplomasi publik tidak hanya menempatkan negara pada program-program pengembangan citra yang positif secara domestik saja tetapi

\footnotetext{
4 United States Information Agency Alumni Association, "What Is Public Diplomacy? http://pdaa.publicdiplomacy.org/?page_id=6. Diakses tanggal 16 Oktober 2014

${ }^{5}$ Wolf Jr, Charles \& Rosen, Brian. 2004. Public Diplomacy: How to Think About and Improve It. Rand Corporation. http://www.rand.org/. Pg.3

${ }^{6}$ U.S. Department of State. 1987. Dictionary of International Relations Terms, Washington, D.C. Pg. 85
} 
juga internasional. Interaksi antara pemerintah dengan berbagai aktor di dalam negeri beperan penting dalam meningkatkan soft power dan implementasinya ke luar negeri. Hal ini memungkinkan adanya berbagai kegiatan, aktivitas dan program yang dapat membentuk keberhasilan diplomasi publik. Diplomasi publik merupakan sarana yang tepat untuk merebut opini publik dengan mempromosikan citra negara. Hal ini dikarenakan diplomasi publik lebih menekankan kepada hegemoni melalui informasi, kebudayaan dan pendidikan. Proses pembentukan citra dan persepsi menjadi hal yang sangat penting karena winning hearts and minds menjadi esensi dan tujuan utama dari diplomasi publik, yang mana akan berdampak dalam memudahkan pencapaian kepentingan nasional yang lebih luas.

Dalam upaya melakukan diplomasi publik, diperlukan kerjasama antar aktor pemerintah dan non-pemerintah yang melibatkan metode diplomasi multi jalur atau yang biasa disebut dengan multi-track diplomacy. Diplomasi ini memiliki relevansi dengan diplomasi publik dikarenakan terdapat peran yang signifikan dari pemerintah hingga media dalam menjalankan diplomasi demi tercapainya kepentingan nasional, yang dalam konteks ini adalah Indonesia terhadap Amerika Serikat. Pada mulanya, Louise Diamond dan John McDonald memperkenalkan konsep multi-track diplomacy sebagai suatu kerangka berpikir dalam menjalankan diplomasi dengan tujuan terciptanya perdamaian. ${ }^{7}$ Perdamaian akan tercipta jika diplomasi yang dilakukan oleh suatu negara melibatkan seluruh track dari diplomasi dan tidak bergantung pada aktor pemerintah saja. Relevansinya dengan praktek diplomasi publik adalah diplomasi publik tidak akan dapat berjalan secara efektif jika beban aktivitas diplomasi publik tersebut hanya pada pemerintah saja. Sejalan dengan tujuan diplomasi publik yang mengedepankan government to people contact maka pemerintah hingga media dapat berperan aktif dan bekerjasama dalam aktivitas diplomasi publik. Kategorisasi tingkatan dalam diplomasi multijalur terbagi menjadi 9, yaitu: Track One: Government, Track Two:

\footnotetext{
${ }^{7}$ Diamond, Louise \& McDonald, John. 1996. Multi-Track Diplomacy: A System Approach to Peace, $3^{\text {rd }}$ Ed. Kumarian Press: University of Michigan. Pg: 20
} 
Nongovernment/Professional, Track Three: Business, Track Four: Private Citizen, Track Five: Research, Training, and Education, Track Six: Activism, Track Seven: Religion, Track Eight: Funding, Track Nine: Communications and Media. ${ }^{8}$

\section{ARGUMEN PENELITIAN}

Praktek diplomasi Indonesia pada masa pemerintahan Presiden Susilo Bambang Yudhoyono menekankan pendekatan soft power dengan metode diplomasi publik. Diplomasi publik Indonesia bertujuan untuk menciptakan citra positif mengenai Indonesia pada publik internasional, khususnya Amerika Serikat, serta menciptakan mutual understanding antara publik domestik dengan publik internasional. Penciptaan opini publik yang positif bagi Indonesia dapat memberikan dampak yang signifikan pada kepentingan politik luar negeri Indonesia dan memperkuat hubungan bilateral IndonesiaAmerika Serikat.

Kepentingan politik luar negeri Indonesia di Amerika Serikat antara lain adalah mempengaruhi keputusan kebijakan luar negeri Amerika Serikat agar lebih memperhitungkan Indonesia dalam kerjasama di bidang ekonomi, keamanan dan pertahanan dan dukungan pada keterlibatan Indonesia dalam konstelasi politik internasional. Indonesia melakukan diplomasi publik secara aktif dalam kancah internasional melalui instrumen-instrumen pertukaran budaya dan pendidikan, kunjungan resmi, dan media massa. Instrumeninstrumen diplomasi publik ini diimplementasikan dengan melibatkan lebih banyak aktor-aktor non-government, atau dengan kata lain dengan meningkatkan government to people relations dan people-to-people relations.

\section{DINAMIKA HUBUNGAN BILATERAL INDONESIA-AMERIKA SERIKAT}


Menilik sejarahnya, hubungan bilateral Indonesia dengan Amerika Serikat telah lama terjalin bahkan sejak sebelum proklamasi kemerdekaan Indonesia pada tahun 1945. Hubungan diplomatik Indonesia dan Amerika Serikat diresmikan dengan didirikannya Kedutaan Besar di masing-masing Negara. ${ }^{9}$ Amerika Serikat dan Indonesia menjalin hubungan yang cukup konstruktif pada prosesnya walaupun seringkali juga mengalami pasang surut. Sejarah mencatat, pada masa pemerintahan Presiden pertama Indonesia, Ir. Soekarno, pada tahun 1949 Amerika Serikat melalui perantara Persatuan Bangsa-Bangsa (PBB) mendukung dan membantu Indonesia lepas dari kekangan Belanda yang masih tidak rela melepaskan wilayah jajahannya. Indonesia berupaya untuk tetap mempertahankan kemerdekaannya dengan melakukan berbagai usaha diplomasi dan berbagai perundingan yang berkaitan dengan perebutan kekuasaan atas berbagai wilayah di Indonesia dan pengakuan kedaulatan Republik Indonesia. ${ }^{10}$

Di masa awal kemerdekaan Indonesia ini pula, dimana Indonesia baru saja mencanangkan prinsip politik luar negeri bebas aktifnya, Indonesia memilih untuk tidak berpihak dari Blok Barat (Amerika Serikat) ataupun Blok Timur (Uni Soviet) namun membentuk Gerakan Non-Blok. ${ }^{11}$ Gerakan NonBlok ini menjadi manuver Presiden Soekarno bagi Indonesia untuk bisa tetap menjadi pihak yang netral namun tetap aktif dalam konstelasi politik Internasional. Hal ini kemudian mempengaruhi hubungan bilateral IndonesiaAmerika Serikat menjadi buruk karena sikap netral Indonesia dianggap sebagai penolakan oleh Amerika Serikat untuk menjalin koalisi.

Memasuki penghujung tahun 1965 hubungan antara Indonesia semakin erat dengan Cina. Hal ini menjadikan Indonesia dianggap mulai dirambahi aliran komunisme dan menjadi jalan pembuka bagi munculnya revolusi untuk menggantikan posisi Presiden Soekarno sebagai penguasa

\footnotetext{
9 Embassy of Indonesia Wahington DC. Bilateral Relations Indonesia-United States. http://www.embassyofindonesia.org/wordpress/?page_id=516. Diakses tanggal 13 Maret 2014.

${ }^{10}$ International Business Publications USA. (2008). Indonesia Diplomatic Handbook. International Business Publications: Washington. Pg: 26-27

${ }^{11}$ Denmark, A. M, et al. (2010). Crafiting a Strategic Vision: A new Era of US-Indonesia Relations. Center for New American Security. Pg. 14.
} 
tunggal Indonesia. Amerika Serikat kembali hadir untuk memberikan bantuan kepada Indonesia dengan tujuan membasmi PKI. Bantuan tersebut disambut baik oleh Presiden Soeharto sebagai Presiden Republik Indonesia menggantikan Soekarno yang dilegitimasi melalui SUPERSEMAR (Surat Perintah Sebelas Maret). Presiden Soeharto mulai mengadakan serangkaian operasi militer untuk membersihkan negara dari bahaya gerakan komunis. ${ }^{12}$ Komitmen Indonesia dalam memberantas komunisme diapresiasi oleh Amerika Serikat dan mampu menormalisasi hubungan Indonesia-Amerika Serikat yang sempat surut.

Namun kemudian pada masa pemerintahan Presiden Soeharto, krisis multidimensi terjadi di Asia dan menyebabkan inflasi terjadi secara besarbesaran atas nilai tukar rupiah terhadap dollar. Indonesia tidak mampu beradaptasi dengan krisis moneter ini yang kemudian menyebabkan keterpurukan pada kondisi ekonomi di Indonesia juga menandai periode akhir masa kepemimpinan Presiden Soeharto. Amerika Serikat kemudian sebagai salah satu anggota pemegang hak suara terbesar di International Monetary Fund (IMF) memberikan pinjaman dana kepada Indonesia. Melalui IMF Amerika membantu Indonesia untuk bangkit dari keterpurukan ekonomi di masa krisis moneter tersebut. Bantuan dari IMF kepada Indonesia ini mengalami kontroversi di publik Indonesia karena bantuan tersebut di satu sisi menjadi penolong untuk mengatasi krisis di Indonesia namun di sisi lain terdapat syarat-syarat yang mengiringi bantuan IMF tersebut. Indonesia menjadi tidak mampu mandiri dalam hal ekonomi karena bantuan dan prasyarat IMF dan Amerika Serikat yang dituangkan dalam Structural Adjustment Program (SAP) yang malah menambah beban negara. ${ }^{13}$

Pada masa pemerintahan presiden-presiden Indonesia selanjutnya, hubungan bilateral Indonesia-Amerika Serikat berada pada masa penyesuaian dan perbaikan yang berkesinambungan. Di awal masa reformasi, pemerintahan

\footnotetext{
${ }^{12}$ Loc. Cit

13 Nugroho, G. 2011. Peran IMF Dalam Penanganan Krisis Ekonomi di Indonesia 1997/1998. http://politik.kompasiana.com/2011/04/05/peran-imf-dalam-penanganan-krisis-ekonomi-di-indonesia19971998-354375.html. Diakses tanggal 12 Februari 2014
} 
Presiden BJ Habiebie belum mampu membentuk relasi yang stabil antara Indonesia dan Amerika Serikat. Peristiwa pelanggaran hak asasi manusia yang terjadi saat Timor-Timur berusaha lepas dari Indonesia juga menjadi perhatian dunia Internasional, khususnya Amerika Serikat. Di masa pemerintahan Presiden Gus Dur dan selanjutnya Presiden Megawati, hubungan bilateral kedua negara, Indonesia dan Amerika Serikat, terus dibina dan dijaga. Saat terjadi peristiwa 9/11 tahun 2001, Amerika Serikat dibawah pemerintahan Presiden George Bush, secara tegas mendeklarasikan kebijakan "war on terror" untuk memerangi terorisme dan sekaligus mencari dukungan internasional terhadap kebijakan tersebut. Indonesia sebagai negara dengan penduduk muslim terbesar di dunia, digandeng oleh Amerika Serikat untuk turut mendukung kebijakan tersebut. ${ }^{14}$

Perhatian khusus Amerika Serikat terhadap Indonesia ini memberikan pengaruh terhadap opini publik masyarakat Indonesia terhadap Amerika Serikat dan begitupun sebaliknya. Indonesia memiliki umat islam terbanyak didunia, namun meskipun kebanyakan dari masyarakat Indonesia bersikap moderat dan mendukung kebijakan war on terror Amerika Serikat, masyarakat Indonesia tetap tidak menyetujui sikap Amerika Serikat atas penyerangan-penyerangan sepihak terhadap Afghanistan dan Irak. ${ }^{15}$ Opini publik yang terbentuk pada masyarakat Indonesia dan Amerika Serikat terhadap satu sama lain pada masa ini adalah cenderung kearah negatif. Selain itu, Amerika Serikat yang terus menerus membantu perekonomian Indonesia dianggap sebagai taktik politik karena bantuan-bantuan Amerika Serikat tidak hanya sekedar "bantuan" namun lebih kepada memberikan "ketergantungan". ${ }^{16}$ Pasang surut hubungan ini lah yang kemudian memunculkan anggapan bahwa Indonesia dan Amerika Serikat adalah hubungan antar negara yang digambarkan "when love and hate collide". Penggambaran bahwa bagaimanapun pasang surutnya hubungan bilateral yang

\footnotetext{
${ }^{14}$ Ibid. Pg. 454.

${ }^{15}$ Loc. Cit.

${ }^{16}$ Gouda, F \& Zaalberg, T. B. 2002. American Visions of the Netherlands East Indies/Indonesia: US Foreign Policy and Indonesian Nationalism 1920-1949. Amsterdam University Press: Amsterdam. Pg. 302-305
} 
terjalin antara Indonesia dengan Amerika Serikat, kedua negara tetap meyakini bahwa masing-masing negara merupakan partner penting bagi kepentingan politik luar negerinya.

Pada masa pemerintahan Presiden Susilo Bambang Yudhoyono, pemerintah Indonesia fokus pada upaya untuk memperbaiki dan memperkuat hubungan bilateral Indonesia dan Amerika Serikat. Tujuan dari upaya memperkuat hubungan bilateral kedua negara ini tentunya tidak terlepas dari pencapaian kepentingan politik luar negeri Indonesia dan upaya untuk meningkatkan peran dan/atau kontribusi Indonesia dalam konstelasi politik internasional dan dalam menghadapi permasalahan global. Amerika Serikat sebagai negeri adidaya tentunya memiliki pengaruh penting bagi Indonesia dan hubungan kedua negara sangat perlu untuk dijaga agar tetap stabil bahkan diperkuat.

Presiden Susilo Bambang Yudhoyono yang mencanangkan diplomasi Indonesia yang bermotto "Thousand friends zero enemy" berkomitmen untuk meningkatkan hubungan bilateral dengan seluruh negara, khususnya negaranegara yang dianggap memiliki prospek yang tinggi dalam pencapaian politik luar negeri Indonesia. Dalam konteks ini, Amerika Serikat dipandang sebagai partner penting bagi Indonesia. Oleh karena itu intensifitas kerjasama dan konsultasi diperlukan demi terciptanya momentum yang berkelanjutan dan terjaganya kemitraan antar kedua negara. Sebagai kelanjutan dari prinsip politik luar negeri Indonesia dibawah pemerintahan Presiden Susilo Bambang Yudhoyono, kerjasama dengan Amerika Serikat terus menerus ditinjau, diperbaiki dan ditingkatkan.

Proses kerjasama bilateral kedua negara pada tahap ini telah mencapai fase equal partnership yang ditandai dengan disepakatinya Indonesia-US Comprehensive Partnership Agreement pada kunjungan kenegaraan Presiden Barack Obama pada tanggal 9-10 November 2010. ${ }^{17}$ Kesepakatan kemitraan komprehensif ini menjadi titik tolak dari tahap baru hubungan bilateral kedua

17 US Department of State. 2010. United States - Indonesia Comprehensive Partnership. Fact Sheet. http://www.state.gov/r/pa/prs/ps/2013/10/215196.htm. Diakses tanggal 13 Maret 2014. 
negara. Sebelum diresmikannya comprehensive partnership ini, hubungan bilateral Indonesia dan Amerika Serikat diimplementasikan berdasarkan Indonesia-US Joint Commission Meeting yang diketuai oleh Menteri Luar Negeri dari masing-masing negara. Kemitraan komprehensif ini didasarkan pada sejumlah nilai bersama yang sangat penting seperti kebebasan, pluralisme, toleransi, demokrasi dan penghormatan terhadap hak-hak asasi manusia.

Presiden Susilo bambang Yudhoyono menegaskan bahwa kemitraan Indonesia dengan Amerika Serikat dibangun dengan tujuan membentuk kemitraan demokratis dan berkomitmen bersama untuk mendorong perdamaian, kebebasan, kemakmuran, penegakan hokum dan toleransi beragama di berbagai kawasan di dunia. ${ }^{18}$ Kerjasama yang dibentuk dalam kemitraan komprehensif ini meliputi kerjasama yang luas di berbagai sektor, yakni pada sektor pendidikan, sektor lingkungan hidup, sektor keamanan, sektor ilmu pengetahuan dan teknologi, sektor perdagangan dan investasi, sektor demokrasi dan hak asasi manusia, sektor energi, dan sektor pangan. ${ }^{19}$

Sektor-sektor yang tercakup dalam kemitraan komprehensif tersebut dibagi dalam kelompok kerja (working groups) yang diketuai oleh masingmasing kementerian yang ditunjuk langsung oleh Presiden dari masing-masing negara. Kementerian dalam hal ini menjadi penanggung jawab dan pengawas atas program-program yang telah dibentuk berdasarkan kelompok kerja yang menjadi tanggung jawabnya. Kemitraan ini menjadi cerminan dari peningkatan hubungan kedua Negara yang berbasis equal partnership atas prinsip saling menghormati dan saling menguntungkan. Sebagai upaya meningkatkan hubungan bilateral kedua negara demokratis terbesar di dunia, kelompok kerja (Working Groups) yang dibentuk atas kesepakatan IndonesiaUS Comperehensive Partnership ini meliputi enam komponen utama yaitu The Democracy and Civil Society Working Group, Education Working Group,

\footnotetext{
18 Ibid.

${ }^{19}$ Website Resmi Presiden Republik Indonesia. 2010. Pidato Sambutan Presiden Susilo Bambang Yudhoyono pada Jamuan Makan Malam Kenegaraan bersama Presiden Amerika Serikat Barack Husein Obama. Istana Negara, 9 november 2010. Http://www.presidenri.go.id/index.php/pidato/2010/11/09/1517.html. Diakses tanggal 13 Maret 2014.
} 
Security Working Group, Environment and Climate Working Group, Energy Working Group, Trade and Investment Working Group. ${ }^{20}$

Kemitraan komprehensif yang dicanangkan Presiden Susilo Bambang Yudhoyono dan Presiden Barack Obama ini tentunya memberikan kerangka bagi pemerintah Amerika Serikat dan Indonesia untuk mempererat dan memperluas kerja sama. Kemitraan ini tidak hanya membangun kerjasama antara Government to Government $(G 2 G)$ namun juga menjadi penanda bahwa kerjasama antar warga masyarakat atau People to People $(P 2 P)$ terakomodir dengan tujuan agar kerjasama yang terbangun adalah kerjasama yang equal dan mutual dan tentunya tujuannya adalah untuk kesejahteraan dan kemakmuran rakyat di masing-masing negara. Indonesia harus menjadikan kemitraan komprehensif ini sebagai alat untuk dapat mencapai kepentingan politik luar negerinya dimana esensi utamanya adalah kerjasama yang saling menguntungkan, bukannya menguntungkan secara sepihak. Dengan dibentuknya kemitraan komprehensif di masa pemerintahan Presiden Susilo Bambang Yudhoyono, hubungan bilateral Indonesia dan Amerika Serikat diharapkan dapat lebih konkret dalam implementasinya karena kemitraan ini juga bertumpu pada hubungan antar warga negara (people to people contact).

\section{PEMBAHASAN}

\section{KONSEP DAN TUJUAN DIPLOMASI PUBLIK INDONESIA DI BAWAH PEMERINTAHAN SUSILO BAMBANG YUDHOYONO}

Dalam konteks Indonesia, terdapat dua alasan utama mengapa praktek diplomasi publik menjadi penting untuk dikembangkan dan ditingkatkan dalam implementasinya. Pertama, seiring dengan motto politik luar negeri yang dicanangkan oleh Presiden Susilo Bambang Yudhoyono yaitu "Thousand friends zero enemy”, Indonesia berupaya untuk lebih mengembangkan dan memperkuat soft power dalam melakukan hubungan bilateral maupun multilateral. Diplomasi publik sebagai elemen dari soft power dipandang 
penting untuk ditingkatkan karena berkaitan erat dengan pembentukan citra positif bagi Indonesia di negara lain, khususnya Amerika Serikat dalam konteks ini. Kedua, Indonesia memandang diplomasi publik menjadi penting untuk digiatkan karena berkaitan dengan posisi Indonesia dalam konstelasi politik internasional dimana Indonesia sedang berupaya untuk meningkatkan perannya baik di kancah regional maupun internasional seperti di ASEAN, G20, UN Peacekeeper dan lain-lain. ${ }^{21}$ Hal ini menjadi perhatian khusus Indonesia karena dengan meningkatkan perannya dalam konstelasi politik internasional tersebut, Indonesia secara tidak langsung akan membentuk citra positif dan membangun kepercayaan negara lain terhadap Indonesia. Nantinya, hal-hal tersebut akan memberikan dampak yang signifikan terhadap pencapaian tujuan politik luar negeri Indonesia terutama dalam konteks politik dan ekonomi. ${ }^{22}$

Konsep diplomasi publik yang dijalankan oleh Indonesia sedikit berbeda dengan praktek yang banyak dilakukan oleh negara-negara lain khususnya negara maju seperti Amerika Serikat. Jika Amerika Serikat melakukan diplomasi publik dengan tujuan khusus mempengaruhi publik luar negeri atau internasional, Indonesia melaksanakan diplomasi publiknya tidak hanya kepada publik internasional tetapi juga kepada publik domestik. ${ }^{23}$ Hal ini dipengaruhi oleh kesadaran bahwa politik internasional banyak dipengaruhi oleh faktor-faktor internal sebuah negara. Di sisi lain dinamika politik dalam negeri juga banyak dipengaruhi oleh berbagai isu-isu internasional. Tujuan utama dari diplomasi publik Indonesia yang diperkenalkan secara resmi adalah to win the hearts and minds of people, domestically and internationally. ${ }^{24}$

Indonesia dalam hal ini juga membenahi dan memberikan pemahaman bagi masyarakat di dalam negeri tentang kebijakan-kebijakan politik dalam

\footnotetext{
${ }^{21}$ Zhida, Jiang. (2012). Indonesia's “Confidence” Diplomacy under the Yudhoyono Government. China Institute of International Studies. http://www.ciis.org.cn/english/2012-12/31/content_5638110.htm. Diakses tanggal 19 Agustus 2014.

${ }^{22}$ Direktorat Diplomasi Publik. Op. Cit. 2010

${ }^{23}$ Tuch, Hans N. 1990. Communicating With the World. St. Martin's Press: New York. Pg. 65

${ }^{24}$ Wawancara dengan Bapak Siuaji Raja, Staff Direktorat Diplomasi Publik, Dirjen Informasi dan Diplomasi Publk, Kementerian Luar Negeri RI. Tanggal 5 Mei 2014.
} 
dan luar negeri Indonesia agar kemudian dapat membentuk opini publik yang lebih komprehensif. Dinamika masyarakat Indonesia yang multietnis dan multikultural menjadi tantangan tersendiri bagi Indonesia untuk terus melakukan aktivitas diplomasi publik di dalam negeri. Pembentukan opini publik terhadap publik domestik ini menjadi landasan untuk kemudian membentuk opini publik internasional. Ketika negara telah berhasil membentuk opini publik masyarakat domestiknya maka akan memudahkan proses pembentukan opini publik internasional. Mutual understanding antara publik domestik dengan pemerintah telah terbentuk sehingga kebijakan pemerintah dapat tercermin dari opini publik domestiknya.

Presiden Susilo Bambang Yudhoyono dimasa awal kepemimpinannya telah menggunakan diplomasi publik untuk membenahi birokrasinya dan melakukan kampanye anti korupsi. Pemerintah menggunakan instrumen diplomasi publik seperti media massa, dan menggandeng aktor-aktor non pemerintah sebagai penggiat kampanye anti korupsi tersebut. Diplomasi publik yang dilakukan pada publik domestik ini ditujukan untuk memberikan pemahaman mengenai bahaya dan seberapa destruktifnya budaya korupsi di Indonesia. Kampanye pemberantasan korupsi yang dilakukan pemerintah ini ternyata sesuai dengan trend dunia dimana berbagai negara juga tengah melakukan kampanye anti korupsi. Diplomasi publik dengan menggunakan diplomasi multi-jalur ini menjadi cara yang cukup efektif untuk memberikan pemahaman bagi publik domestik.

Isu dalam negeri maupun isu internasional bersifat intermestik atau memiliki keterkaitan satu sama lainnya. Oleh karena itu konsep diplomasi publik yang dianut oleh Indonesia menjadi titik dasar yang baik bagi aktivitas diplomasi publiknya saat ini dan di masa depan. Antara pemerintah dan rakyat harus memiliki satu suara untuk menjaga kredibilitas pemerintah sendiri. Dengan demikian, diplomasi konvensional yang hanya melibatkan komunikasi antar pemerintah tidak cukup untuk mengelola terlebih menyelesaikan isu-isu dan permasalahan internasional yang semakin kompleks dan fluid saat ini. Sebagai jawaban dari tantangan tersebut, pemerintah Indonesia membentuk 
sebuah mekanisme yang bisa menjembatani dinamika luar negeri untuk kemajuan dalam negeri yaitu diplomasi publik. Dengan demikian, publik dalam negeri diharapkan dapat semakin mengerti berbagai masalah internasional khususnya isu-isu yang melewati batas-batas negara di dalam dunia internasional yang semakin terbuka dan kompleks. Selain itu, dapat pula tercipta mutual understanding dengan publik internasional, yang dalam konteks ini adalah Amerika Serikat, sebagai upaya memperkuat hubungan bilateral antar negara dan tercapainya kepentingan politik luar negeri Indonesia baik pada tingkat regional maupun internasional. ${ }^{25}$

Diplomasi publik pada dasarnya ditujukan sebagai alat politik yang digunakan pemerintah untuk memahami budaya dan perilaku negara lain dengan tujuan mempengaruhi opini dan tindakan untuk mencapai kepentingan di negara tersebut. ${ }^{26}$ Dalam konteks Indonesia, diplomasi publik yang dilakukan adalah sebagai upaya untuk mempengaruhi opini publik baik domestik ataupun internasional dengan maksud pencapaian kepentingan luar negeri. Oleh karena itu untuk mengetahui tujuan utama dari diplomasi publik maka perlu terlebih dahulu mengetahui kepentingan politik luar negerinya. Presiden Susilo Bambang Yudhoyono sejak awal masa pemerintahannya telah berupaya untuk membentuk dan menjaga kondisi stabil dalam negeri Indonesia agar dapat menjalankan kerjasama bilateral maupun multilateral yang lebih komprehensif. Saat ini peranan diplomasi Indonesia lebih memiliki nilai baru karena tidak ada kendala internal dalam menjalin hubungan diplomatis dengan negara-negara yang lebih maju. Indonesia memiliki kesetaraan yang sama dalam menjalin hubungan diplomatiknya karena telah bicara dalam kerangka bahasan yang sama, telah menjunjung tinggi demokrasi dan penghormatan terhadap nilai-nilai HAM dan pluralisme sehingga lebih nyaman berinteraksi dengan negara lain. Kondisi tersebut membentuk

\footnotetext{
25 Ibid

${ }^{26}$ Effendi, Tonny D. 2011. Diplomasi Publik Jepang: Perkembangan dan Tantangan. Ghalia Indonesia: Bogor. Pg: 10
} 
kepercayaan tinggi bagi Indonesia untuk lebih aktif dalam merintis kerjasama antarnegara. $^{27}$

Peluang Indonesia sebagai role model dalam diplomasi saat ini ditunjukkan dengan Indonesia yang memiliki peran sentral pada beberapa pertemuan antar negara di tingkat regional, multilateral dan internasional. Indonesia bergabung dalam pertemuan negara G-20 dan Indonesia mampu menyumbangkan saran dalam membahas krisis keuangan global. Selain itu, Indonesia menjadi satu-satunya negara berkembang di ASEAN yang diundang pada pertemuan negara-negara maju atau G-8 yang dijadikan ajang pertemuan tingkat dunia khusus bagi negara yang memiliki kekuatan ekonomi yang dianggap mapan. ${ }^{28}$ Demi menjaga dan meningkatkan peran-peran sentral tersebut Indonesia memerlukan kerjasama bilateral maupun internasional yang dibangun atas asas equal partnership dan mutual understanding sebagai upaya mendapatkan kepercayaan internasional dan terbentuknya long-term cooperation antar negara. Amerika dalam hal ini menjadi partner penting bagi Indonesia karena Amerika dapat menjadi pendukung Indonesia dalam pencapaian politik luar negerinya serta perluasan dan penguatan peran Indonesia pada tingkat regional maupun multilateral.

Kepentingan politik luar negeri Indonesia terhadap Amerika dapat dibagi menjadi tiga poin utama. ${ }^{29}$ Pertama, kepentingan dalam aspek politik dan keamanan. Indonesia membutuhkan Amerika sebagai pendukung Indonesia dalam konstelasi politik Internasional dan terjaganya stabilitas politik dan keamanan di daerah kawasan Indonesia. Kasus HAM yang dulu dialami oleh Indonesia sempat memberikan keraguan bagi Amerika untuk membantu Indonesia dalam hal militer dan keamanan namun seiring berjalannya proses

\footnotetext{
${ }^{27}$ Zhida, Jiang. Op. Cit. (2012).

${ }^{28}$ Reid, Anthony. (2012). Indonesia's New Prominence in the World dalam Indonesia Rising: The Repositioning of Asia's Third Giant. Institute of Southeast Asian Studies: Singapore. Pg. 5-6.

${ }^{29}$ Denmark, A. M, et al. 2010. Crafiting a Strategic Vision: A new Era of US-Indonesia Relations. Center for New American Security. Pg. 41-42
} 
demokrasi di Indonesia dengan baik, Amerika kembali menaruh kepercayaan untuk melangsungkan kerjasama militer kedua negara. Kedua, dalam aspek ekonomi, Indonesia membutuhkan Amerika dalam upaya mereformasi pembangunan ekonomi di Indonesia dan mendukung Indonesia dalam upayanya untuk berperan sebagai new emerging power di Asia. Yang terakhir adalah pada people-to-people exchange yang meliputi berbagai aspek seperti pendidikan, kebudayaan, dan lain-lain. Indonesia membutuhkan Amerika untuk terus berkomitmen membantu peningkatan kualitas sumber daya manusia dan tenaga kerja Indonesia. Hal ini menjadi penting karena sumber daya manusia Indonesia menjadi aset yang crucial bagi Indonesia yang notabene merupakan negara berpenduduk terbesar ke-4 di dunia.

Sebagai upaya melancarkan kepentingan politik luar negeri tersebut, Indonesia dengan demikian melakukan diplomasi publik terhadap Amerika. Diplomasi publik yang dilakukan oleh Indonesia menggunakan instrumeninstrumen budaya, pendidikan, ekonomi dan media serta menggandeng seluruh elemen negara dari pemerintah hingga individu. Tujuan utamanya adalah to win the hearts and minds of the public agar terbentuk opini publik yang dapat mempengaruhi publik Amerika sehingga kerjasama bilateral kedua negara senantiasa terjaga dan terjalin dalam jangka panjang.

\section{IMPLIKASI DIPLOMASI PUBLIK INDONESIA DALAM MEMPERKUAT HUBUNGAN BILATERAL INDONESIA-AMERIKA SERIKAT DAN PENCAPAIAN POLITIK LUAR NEGERI INDONESIA}

Dalam memperkuat hubungan bilateral Indonesia-Amerika Serikat, diplomasi publik memberikan sumbangsih dengan menciptakan citra positif dan opini publik Amerika yang mampu mempengaruhi kebijakan Amerika Serikat terhadap Indonesia. Sebagaimana yang telah dijelaskan pada bab sebelumnya, Indonesia dan Amerika Serikat pernah mengalami masa dimana hubungan bilateralnya tidak dapat berjalan dengan baik karena isu-isu internasional yang mempengaruhi citra Indonesia. Indonesia di masa awal reformasi berjuang keras untuk memperbaiki citra dan kepercayaan 
masyarakat internasional atas Indonesia. Penurunan citra dan kepercayaan masyarakat internasional ini adalah akibat dari permasalahan yang dialami Indonesia seperti referendum Timor-Timur, pelanggaran HAM, sistem pemerintahan yang otoriter dan KKN (Korupsi, Kolusi dan Nepotisme) serta isu terorisme. Selain itu berkaitan dengan isu terorisme, masyarakat barat termasuk Amerika seakan-akan terkena islamophobia dimana Indonesia sebagai negara berpenduduk muslim terbesar di dunia turut terkena akibatnya. Permasalahan-permasalahan tersebut tidak dapat diselesaikan jika pemerintah berjalan sendiri atau dengan kata lain hanya menjalankan diplomasi pada tataran G2G (Government to Government) dan hanya menekankan pada hard power. Oleh karena itu, Indonesia menginisiasi diplomasi dengan pendekatan soft power dengan metode diplomasi publik.

Diplomasi publik Indonesia yang dilaksanakan dengan menggunakan instrumen-instrumen seperti pertukaran kebudayaan dan pendidikan, kunjungan resmi dan media sosial memberikan pengaruh yang cukup signifikan terhadap pembentukan citra positif dan kepercayaan masyarakat internasional, khususnya Amerika, terhadap Indonesia. Melalui instrumen budaya, program-program budaya yang dilakukan Indonesia menghasilkan antusiasme publik Amerika yang semakin signifikan untuk menikmati bahkan mempelajari budaya Indonesia. Rumah Budaya Indonesia yang dicanangkan Kementerian Pendidikan dan Kebudayaan Republik Indonesia berhasil meraih antusiasme publik Amerika dengan pertunjukan-pertunjukan seni Indonesia.

Salah satu pertunjukan seni yang berhasil menarik minat publik Amerika adalah pertunjukan gamelan. Saat ini telah terdapat kelompok pemain gamelan yang tersebar di 45 negara bagian dari 50 negara bagian di AS. Atase Pendidikan dan Kebudayaan Kedubes RI di AS juga menyatakan bahwa komunitas gamelan di Amerika telah mencapai 400 komunitas gamelan. Mayoritas dari komunitas gamelan tersebut berbasis di perguruan tinggi yakni menjadi bagian dari kegiatan ekstrakurikuler. Dari 400 komunitas 
gamelan tersebut, 127 komunitas aktif berlatih dan menggelar pementasan. ${ }^{30}$ Selain gamelan, alat musik tradisional Indonesia seperti angklung juga mendapatkan apresiasi positif dari masyarakat Amerika. Indonesia memiliki program House of Angklung yang berbasis di Washington D.C dan salah satu aktivitasnya adalah Angklung Goes to School dimana alat musik angklung diperkenalkan di sekolah-sekolah di Amerika. Selain itu Indonesia juga berhasil memecahkan rekor dunia "Guinness World Records" permainan angklung dengan peserta multibangsa terbanyak dengan lebih dari lima ribu orang memainkan alat musik angklung di National Mall-Washington Monument Park, Washington D.C. ${ }^{31}$

Selain kesenian alat musik Indonesia, upaya Indonesia dalam mempromosikan batik juga diapresiasi dengan sangat baik oleh warga Amerika. Kedutaan Besar Indonesia, Washington D.C, memfasilitasi penyelenggaraan American Batik Design Competition (ABDC) yang dilaksanakan sebagai event tahunan sejak tahun $2011 .^{32}$ Hal ini menunjukkan bahwa batik mampu berasimilasi dengan kebudayaan Amerika, dapat diterima dengan baik dan disambut dengan antusiasme yang tinggi oleh masyarakat Amerika. Batik mampu menjadi instrumen diplomasi publik yang efektif karena telah menjadi seni yang mendunia sebagaimana dinobatkan oleh UNESCO sebagai kekayaan seni tak benda pada tahun 2009. Selain itu kesenian batik mudah diserap oleh masyarakat internasional, dan kegunaan batik terjangkau hingga ke ranah industri fashion. Ketertarikan publik Amerika terhadap batik mampu meningkatkan antusiasme terhadap Indonesia dan menjadi penjembatan kebudayaan dan relasi antar masyarakat yang menjadi poin penting dalam hubungan bilateral Indonesia-Amerika.

\footnotetext{
${ }^{30}$ Napitupulu, Ester. 2014. Gamelan, Orkestra Jawa yang Populer di Amerika. Kompas Online. http://travel.kompas.com/read/2014/01/16/1040553/Gamelan.Orkestra.Jawa.yang.Justru.Populer.di.A merika. Diakses tanggal 15 Juli 2014

31 Suryanto. 2010. Indonesia Cetak Rekor Dunia Permainan Angklung di Amerika. http://www.antaranews.com/berita/266748/indonesia-cetak-rekor-dunia-permainan-angklung-di-amerika. Diakses tanggal 16 September 2014.

32 American Batik Design Competition. http://americanbatik.embassyofindonesia.org/. Diakses tanggal 28 Juli 2014
} 
Di lain sisi, makanan khas Indonesia pun memberikan kontribusi dalam membangun apresiasi publik Amerika terhadap Indonesia. Indonesia mampu berpartisipasi dalam ajang pameran Fancy Food Show (FFS) di Amerika. Partisipasi Indonesia ini memberikan kontribusi dalam kinerja ekspor makanan Indonesia di Amerika. Dimana menurut data US Department of Commerce yang diolah Kantor Atase Perdagangan Indonesia, ekspor makanan dan minuman dari Indonesia ke A.S. tahun 2013 mencapai \$632 juta dollar. Ekspor makanan ini meliputi produk kopi, teh, rempah-rempah, makanan olahan, dan minuman. ${ }^{33}$

Program-program diplomasi publik melalui instrumen budaya selain menarik antusiasme publik Amerika di negara mereka juga menarik wisatawan Amerika berkunjung ke Indonesia. Melalui intrumen-instrumen budaya tersebut, Indonesia secara aktif melakukan promosi-promosi pariwisata Indonesia dengan bekerjasama dengan aktor-aktor non-pemerintah seperti artis dan pihak-pihak manajemen pariwisata swasta. Kementerian Pariwisata sebagai contoh menjadikan artis Richard Gere sebagai duta pariwisata Indonesia untuk Amerika berkenaan dengan kunjungannya di Candi Borobudur pada tahun 2011. ${ }^{34}$ Richard Gere sebagai aktor senior di Amerika dijadikan duta pariwisata memberikan kesempatan bagi Indonesia untuk membuka peluang pariwisata yang lebih besar.

Langkah-langkah seperti ini memberikan pengaruh yang positif tidak hanya pada aspek pariwisata Indonesia namun juga pada aspek ekonomi. Dengan melakukan diplomasi publik, memberikan kesempatan bagi Indonesia untuk mempromosikan dan membentuk branding-nya dengan lebih efektif dibanding jika dilakukan hanya dengan melalui first track diplomacy. Selain karena tidak mengakomodir seluruh elemen negara, promosi Indonesian

\footnotetext{
${ }^{33}$ Atase Perdagangan RI Wahington D.C. 2014. Taste Remarkable Indonesia. Press Release: KBRI Washington D.C

34 Antara News. 2011. Ministry to Offer Richard Gere as Tourism Ambassador. http://www.antara.co.id/en/news/72869/ministry-to-offer-richard-gere-as-tourism-ambassador dan The Jakarta Globe. 2011. Actor Richard Gere, Drawn by Karma, Planning Temple Movie. http://www.thejakartaglobe.com/archive/actor-richard-gere-drawn-by-karma-to-borobudur-planning-templemovie/. Diakses tanggal 16 September 2014.
} 
branding juga akan lebih kaku dalam tataran pemerintah jika bergerak sendirian. Oleh karena itu, diplomasi publik yang dilakukan melalui instrumen budaya memerlukan lebih banyak keterlibatan pihak-pihak non-pemerintah.

Lebih lanjut, melalui instrumen pendidikan, kerjasama Indonesia dengan Amerika baik melalui institusi pemerintahan resmi ataupun institusiinstitusi seperti USAID dan AMINEF telah menghasilkan peningkatan yang signifikan dalam proses pertukaran pelajar dan mahasiswa. Diplomasi publik yang dicanangkan melalui instrumen pendidikan ini meliputi programprogram pertukaran pelajar dan beasiswa. Pencapaiannya dapat dilihat dari semakin meningkatnya antusiasme pelajar baik dari Indonesia maupun Amerika untuk mengikuti program pertukaran pendidikan. Saat ini, terdapat kurang lebih 7.000 warga Indonesia yang belajar di Amerika Serikat dan pelajar dari Amerika Serikat pun semakin bertambah dari tahun ke tahun. ${ }^{35}$

Kunjungan-kunjungan yang dilakukan sebagai program diplomasi publik Indonesia juga memberikan kontribusi positif bagi Indonesia. Kunjungan-kunjungan yang dilakukan pemuka agama ke Amerika dalam rangka interfaith dialogue memberikan kesempatan bagi Indonesia untuk menjelaskan kehidupan berdemokrasi di Indonesia dimana demokrasi tetap dapat berjalan dengan cukup stabil di dalam masyakarat yang plural dan moderat. Sejauh ini Indonesia telah mengadakan berbagai kunjungan terkait interfaith dialogue dengan kerjasama berbagai pihak dari pemerintah dan nonpemerintah. Kunjungan yang yang dilakukan beberapa tokoh agama Indonesia dalam kegiatan Interfaith Dialogue di Universitas California difasilitasi oleh Konsulat Jenderal Republik Indonesia (KJRI) San Fransisco bekerja sama dengan Center of Southeast Studies, University of California at Berkeley (UCB).

Interfaith Dialogue ini diisi oleh pembicara yang merupakan tokohtokoh agama Indonesia yang berkunjung ke Amerika, antara lain Prof. Dr. Musa Asy’arie, (Rektor UIN Sunan Kaliajaga Yogyakarta), Dr. Jamhari Maruf

\footnotetext{
${ }^{35}$ Embassy of the United States. Belajar di Amerika Serikat. http://indonesian.jakarta.usembassy.gov/studi.html. Diakses tanggal 15 Juli 2014
} 
(Wakil Rekor UIN Syarif Hidayatullah Jakarta), Prof. Dr. Antonius Eddy Kristiyanto (Sekolah Tinggi Filsafat Driyarkara Jakarta) dan Pendeta Joas Adiprasetya (Sekolah Tinggi Teologi Jakarta). Dialog ini mendapatkan apresiasi yang baik dari Dr. Hardler, Ketua Southeast Asia Studies dan para mahasiswa yang menjadi partisipan dalam dialog tersebut. ${ }^{36}$ Interfaith dialogue ini dilaksanakan sebagai salah satu upaya Indonesia untuk memperkenalkan dan memberikan informasi yang lebih menyeluruh mengenai keberagaman budaya dan agama di Indonesia serta kehidupan bertoleransi.

Selain itu juga diselenggarakan Jakarta Open Forum dengan mengundang Imam Islamic Cultural Center di New York, Imam Shamsi Ali, yang berkebangsaan Indonesia, untuk memberikan ceramah mengenai kehidupan muslim di Amerika dan bagaimana beliau berupaya untuk mempromosikan toleransi antar umat beragama dengan mengambil contoh di Indonesia. ${ }^{37}$ Pembentukan opini bahwa Indonesia adalah negara yang aman dan bersahabat tidak dapat dijalankan oleh pemerintah tanpa dukungan dan bantuan aktor-aktor non-government seperti akademisi, tokoh agama, dan individu. Kemudian disamping menjalankan interfaith dialogue, Indonesia juga aktif mengadakan program pertukaran pelajar/mahasiswa dalam rangka memperkenalkan islam dan pluralisme di Indonesia. Melalui peningkatan people-to-people contact $(\mathrm{P} 2 \mathrm{P})$ seperti ini proses pembentukan opini publik menjadi lebih efektif karena interaksi secara langsung yang memudahkan terjalinnya kesepahaman antar masyarakat. Melalui forum-forum dan program-program diatas Indonesia membentuk citra dimana Indonesia adalah negara yang toleran, plural dan aman. ${ }^{38}$

Selain menciptakan citra tersebut, Indonesia juga membentuk citra sebagai negara demokratis dan sebagai negara dimana agama dan demokrasi

\footnotetext{
36 Berita Perwakilan Kementerian Luar Negeri RI. Op. Cit. 2013.

${ }^{37}$ USINDO. 2013. Jakarta Open Forum: Interfaith Dialogue Lessons Learned for Muslims in America. www.usindo.org: Jakarta. Diakses Tangga 16 September 2014

38 Sucahyo, Nurhadi. 2012. Mahasiswi Amerika Belajar Kebudayaan Islam Jawa. VOA Indonesia. http://www.voaindonesia.com/content/mahasiswi-amerika-belajar-kebudayaan-islam-jawa140822683/105502.html. Diakses tanggal 16 September 2014
} 
dapat berjalan harmonis. Citra ini dicapai melalui upaya-upaya Indonesia yang terus aktif membenahi praktek demokrasinya dan mempromosikan demokrasi di kancah regional dan multilateral. Program diplomasi publik yang mendukung upaya tersebut adalah Bali Democracy Forum (BDF). BDF merupakan inisiatif Indonesia dalam membentuk forum dimana Indonesia dapat mempromosikan demokrasi sekaligus mempromosikan Indonesia di kancah internasional. BDF merupakan forum tahunan yang mulai diselenggarakan oleh Indonesia pada tahun 2008 dan sejauh ini telah diselenggarakan sebanyak enam kali. Tujuan dari forum ini adalah sebagai wadah sharing experience and knowledge khususnya pada bidang demokrasi. Indonesia menginisiasi forum ini sebagai aktualisasi peran Indonesia dalam mempromosikan demokrasi di seluruh dunia. Forum diskusi antar negara ini didasarkan pada keperluan untuk mengorganisasi pembelajaran dialog yang komprehensif dalam demokrasi. Selain itu juga bertujuan untuj mempromosikan kerjasama antar negara dalam pengembangan kelembagaan sosial dan politik untuk kepemerintahan yang demokratik. ${ }^{39}$

Diplomasi publik yang dijalankan Indonesia dengan membentuk BDF ini menjadi kesempatan bagi Indonesia untuk mempromosikan dan mengembangkan demokrasi di Asia yang akan berdampak pada pengembangan demokrasi di dalam negeri serta untuk memperoleh dukungan internasional terhadap kepentingan Indonesia. Selain itu juga untuk meningkatkan peran Indonesia dalam kerjasama antar negara dan tentunya memperoleh kepercayaan masyarakat internasional terhadap Indonesia sebagai negara demokratis, plural, moderat dan aman. Keberhasilan Indonesia dalam menjalankan BDF mencerminkan kepercayaan yang meningkat oleh negaranegara lain termasuk Amerika terhadap peran Indonesia, khususnya dalam mempromosikan demokrasi. Dengan menjalankan BDF, upaya Indonesia dalam membentuk citra sebagai negara demokratis ketiga di dunia setelah Amerika dan India dapat dikatakan berhasil. Hal ini diperkuat dengan

\footnotetext{
${ }^{39}$ Website BDF. What is Bali Democracy Forum. http://bdf.kemlu.go.id/index.php?option=com_content\&view=article\&id=445\&Itemid=106\&lang=en. Diakses tanggal 17 September 2014.
} 


\section{Global Insight Journal}

pernyataan-pernyataan yang dikemukakan oleh beberapa tokoh pemerintahan Amerika. Pernyataan resmi yang dikeluarkan oleh tokoh-tokoh sentral ini juga menjadi bukti bahwa diplomasi publik Indonesia berperan dalam membentuk mutual understanding antara Indonesia dengan publik internasional, khususnya Amerika.

Ketika Duta Besar RI untuk Amerika mengunjungi salah satu anggota kongres Amerika yang beragama islam, anggota kongres tersebut memuji demokrasi yang berjalan di Indonesia dan mengatakan bahwa negara Arab yang diidentikkan dengan Islam harus belajar banyak dari Indonesia. ${ }^{40} \mathrm{Hal}$ ini menunjukkan bahwa Indonesia telah berhasil menunjukkan bahwa Indonesia adalah negara yang aman, dimana demokrasi dan agama dapat berjalan dengan cukup baik. Kunjungan yang dilakukan oleh Duta Besar RI tersebut juga merupakan upaya dari diplomasi publik dimana ditujukan untuk saling bertukar pandangan yang secara tidak langsung akan mempengaruhi pandangan mengenai Indonesia.

Presiden Obama dalam sambutannya saat melangsungkan rapat bilateral bersama Presiden Susilo Bambang Yudhoyono menyatakan bahwa Indonesia telah dikenal sebagai salah satu negara demokrasi terbesar dan negara muslim terbesar di dunia memiliki pengaruh penting tidak hanya dalam perkembangan demokrasi dunia namun juga sebagai partner penting Amerika Serikat. ${ }^{41}$ Pernyataan tersebut menandakan bahwa Indonesia di masa pemerintahan Presiden Susilo Bambang Yudhoyono telah mencapai tujuan diplomasi publiknya dalam membentuk opini positif mengenai Indonesia. Indonesia saat ini telah dikenal sebagai negara demokrasi terbesar ketiga didunia, sebagai negara dengan penduduk muslim terbanyak di dunia dan negara dimana demokrasi, pluralisme dan agama dapat berjalan beriringan dengan harmonis.

\footnotetext{
${ }^{40}$ Kedutaan Besar RI Washington D.C. (2014). Ditemui Dubes Ri: Anggota Kongres Muslim Amerika Puji Demokrasi Di Indonesia. Press Release. http://www.embassyofindonesia.org/wordpress/wpcontent/uploads/2014/07/PR-Keith-Ellison.pdf. Diakses tanggal 8 Agustus 2014.

${ }^{41}$ Sambutan Presiden Barack Obama seletah rapat bilateral bersama President Susilo Bambang Yudhoyono di Shangri-La Hotel, Singapore, 15 November 2009. http://www.whitehouse.gov/the-press-office/remarkspresident-obama-and-president-yudhoyono-indonesia-after-bilateral-meeting. Diakses tanggal 27 Juni 2014.
} 
Presiden Susilo Bambang Yudhoyono yang secara konsisten menekankan diplomasi soft power selama dua periode masa jabatannya memberikan sumbangsih dalam pembentukan politik dalam dan luar negeri yang dapat dikatakan stabil. Pembentukan citra positif Indonesia tersebut pada akhirnya berdampak pada tingkat kepercayaan Amerika dalam melakukan kerjasama dengan Indonesia. Upaya diplomasi Indonesia di masa awal pemerintahan Susilo Bambang Yudhoyno dengan penekanan pada pendekatan soft power dengan metode diplomasi publik telah berhasil memperbaiki citra negatif Indonesia dan membentuk serta meningkatkan dukungan dan kepercayaan masyarakat Internasional terhadap Indonesia. Pada periode kedua pemerintahan Susilo Bambang Yudhoyono, Indonesia - Amerika Serikat memasuki babak baru dalam hubungan bilateralnya yang ditandai dengan penandatangan Comprehensive Partnership Agreement (CPA) RI-US pada tahun 2010.

Kesepakatan CPA ini menandai bahwa Indonesia mendapatkan kepercayaan oleh Amerika untuk membentuk kerjasama yang komprehensif dengan asas equal partnership dan mutual understanding. Hal ini diperkuat dengan pernyataan Hillary Clinton mengenai Indonesia sebagai mitra bilateral yang menjanjikan. Hillary menyatakan bahwa Indonesi-Amerika Serikat telah mencapai banyak kemajuan dalam hubungan bilateral kedua negara. Indonesia mampu memainkan peran yang baik tidak hanya dalam proses demokrasi namun juga pada isu-isu seperti lingkungan, perubahan iklim dan lain-lain. ${ }^{42}$ Dalam ranah kerjasama CPA ini Indonesia - Amerika Serikat sepakat untuk mengakomodir seluruh elemen negara dalam menjalankan perjanjian demi kesuksesan dan CPA tersebut dan pemeliharaan hubungan bilateral jangka panjang. Oleh karena itu, Indonesia tetap melaksanakan aktivitas-aktivitas diplomasi publik yang sesuai dengan dan mendukung kesepakatan kedua negara. CPA merupakan kerjasama bilateral kedua negara yang merupakan tanggung jawab Menteri Luar Negeri. Sejauh ini telah diadakan tiga kali

\footnotetext{
${ }^{42}$ VOA. 2010. Clinton Sebut Indonesia sebagai Mitra Bilateral yang Hebat. http://www.voaindonesia.com/content/menlu-marty-hubungan-indonesia-as-terbaik-saat-ini103198294/83887.html. Diakses tanggal 16 September 2014.
} 
pertemuan antara Menlu Hillary Clinton dan Menlu Marty Natalegawa dalam Joint Commission Meeting yang tujuannya adalah membahas pencapaian program-program dalam kerjasama komprehensif ini. CPA tersebut membawahi beberapa Working Groups (WG) yang menjalankan programprogram yang relevan dengan WG yang ditangani. WG ini meliputi bidang demokrasi dan masyarakat sosial, pendidikan, keamanan, energi, perubahan iklim, dan teknologi. ${ }^{43}$

Kementerian Luar Negeri RI Direktorat Diplomasi Publik membawahi Working Group yang bergerak pada bidang demokrasi dan mayarakat sosial (Working Group in Democracy and Civil Society (WGDCS)). WGDCS ini merupakan kesepakatan Indonesia-Amerika Serikat yang bergerak dalam pembangunan dan peningkatan proses demokrasi di kedua negara melalui kegiatan program-program yang relevan. Indonesia dan Amerika Serikat secara rutin melakukan pertemuan Joint Commission Meeting (JCM) setiap tahun, dan Mid Term Review di antara JCM untuk mereview seluruh kegiatan yang telah dilaksanakan dalam working groups. Kegiatan yang diselenggarakan dalam konteks WGDCS yang terkini antara lain adalah Civil Society Organizations (CSOs) Consultation Forum, Women CSOs Consultation Forum dan melanjutkan Bali Democracy Forum.

Pada intinya, kegiatan CSO dalam WGDCS ini bertujuan untuk mempertemukan CSO Indonesia dan CSO Amerika Serikat yang bergerak di bidang demokrasi, good governance, dan women in politics, dalam rangka sharing of experiences and lessons learnt mengenai isu-isu politik dan demokrasi di masing-masing negara yang dapat bermanfaat bagi pembangunan dan terjaganya stabilitas politik di masing-masing negara. ${ }^{44}$ Kegiatan ini juga memberikan kesempatan untuk meningkatkan kapabilitas Indonesia dalam bidang politik, khususnya peningkatan peran wanita. Dalam ranah CPA sejauh ini telah terdapat beberapa pencapaian yang juga menjadi hasil dari kerjasama diplomasi pemerintah yang menggandeng aktor-aktor

${ }^{43}$ US Department of State. Op. Cit. 2010.

${ }^{44}$ Ibid 
non-pemerintah sehingga kerjasama komprehensif ini dapat berjalan dengan baik sejauh ini.

Hubungan RI - AS ini membawa manfaat kesejahteraan serta peluang yang lebih besar bagi rakyat Indonesia. Volume perdagangan Indonesia Amerika-Serikat pada tahun 2012 telah melebihi USD22 milyar, sementara investasi AS di Indonesia sejak tahun 2010 tetap berada di 5 besar. Di bidang pendidikan, sudah terjalin sekitar 15 kerjasama antara Perguruan Tinggi dan skema "double degree", antara lain melibatkan Ohio University, ITB, University of Florida; maupun kerjasama student exchange antara lain University of Hawaii dengan Universitas Islam Indonesia dan Universitas Gadjah Mada. Indonesia juga mendapatkan hibah dari AS sebesar 600 juta dollar melalui program Millennium Challenge Corporation (MCC) di bidang kesehatan nutrisi anak, modernisasi sistem pengadaan dan green prosperity serta membantu modernisasi sistem pertahanan Indonesia dengan kesepakatan untuk memberikan 24 pesawat F-16 melalui fasilitas Excess Defense Article (EDA). ${ }^{45}$

Dengan demikian, hubungan Indonesia - Amerika Serikat dapat dikatakan semakin membaik walaupun masih terdapat masalah-masalah bilateral yang belum terselesaikan. Namun, dengan disepakatinya CPA tersebut hubungan bilateral Indonesia - Amerika telah masuk ke babak baru karena dibangun atas dasar equal partnership dan dengan berorientasi ke depan. Hal ini tidak terlepas dari upaya diplomasi publik Indonesia yang terus menerus menjaga opini publik masyarakat baik domestik maupun internasional agar tetap dalam ranah positif sehingga dapat membantu dalam peningkatan kapabilitas dan posisi sentral Indonesia baik di kancah regional maupun multilateral.

\section{PENUTUP}

\section{KESIMPULAN}

\footnotetext{
${ }^{45}$ Djalal, Dino P. (2013). Surat Terbuka kepada Diaspora Indonesia di Amerika Serikat. www.embassyofindonesia.org. Diakses tanggal 20 Juli 2014.
} 
Diplomasi Indonesia pada masa pemerintahan Presiden Susilo Bambang Yudhoyono dihadapkan pada berbagai perubahan dan pergeseran kekuatan dalam lingkungan strategis global dan regional sebagai dampak pada aspek hubungan antarnegara. Peta kekuatan dunia sedang mengalami transisi menjadi kekuatan nonpolar dimana sistem internasional ini muncul dengan ditandai oleh banyaknya poros kekuatan yang independen sehingga tidak ada kekuatan yang dominan. Pelakupelaku dalam sistem nonpolar ini tidak hanya negara, tetapi juga pelaku non negara seperti organisasi-organisasi dan lembaga-lembaga internasional. Perubahan sistem internasional ini memberikan peluang bagi Indonesia untuk meningkatkan perannya dalam menghadapi berbagai tantangan baik pada tataran regional maupun global.

Dengan adanya peluang tersebut Indonesia kemudian perlu meningkatkan aktivitas diplomasinya. Negara yang memiliki keunggulan diplomasi akan memperoleh banyak manfaat baik bagi kemajuan pembangunan dan menjaga integritas negerinya, maupun untuk memperkuat posisi tawar dalam rangka hubungan internasionalnya. Oleh karena itu, meningkatkan aktivitas dan keunggulan diplomasi merupakan kebijakan yang harus dilakukan Indonesia. Di dalam menghadapi era global ini Indonesia harus mengupayakan peningkatan kemampuan diplomasinya, sehingga akan menumbuhkan kepercayaan internasional kepada Indonesia dalam menjalankan kerjasama bilateral maupun multilateral.

Pada aspek ini diplomasi publik mengambil peran penting, karena saat ini kekuatan diplomasi Indonesia tidak lagi terletak pada the power of argument seperti pada masa Presiden Soekarno namun terletak pada kerjasama yang komprehensif baik dalam ranah pemerintah-pemerintah ataupun pemerintah-masyarakat. Diplomasi publik menjadi aspek penting dalam upaya mendapatkan kepercayaan internasional yang pada akhirnya berkaitan erat dengan program-program pencapaian kepentingan nasional, karena dengan kepercayaan tersebut akan memudahkan Indonesia dalam mancapai tujuan nasional baik jangka pendek maupun jangka panjang. Dengan berdasar dari pola pemikiran seperti ini Indonesia melakukan diplomasi publik terhadap negara-negara yang dianggap menjadi partner penting Indonesia dalam upaya mencapai kepentingan politik luar negerinya. Pada konteks ini Amerika menjadi negara yang patut digandeng oleh Indonesia karena Amerika sebagai negara 
Adidaya tentunya akan memberi manfaat bagi Indonesia. Selain itu Indonesia memiliki kepentingan politik, ekonomi dan sosial budaya terhadap Amerika dimana cukup crucial dalam menentukan posisi Indonesia pada kontelasi politik Internasional dan peran sentral Indonesia di forum-forum bilateral maupun multilateral.

Hal penting dalam temuan penelitian ini adalah, pertama diplomasi publik yang dilakukan Indonesia bertujuan untuk menciptakan citra positif bagi Indonesia. Penciptaan citra positif ini ditujukan agar international society memiliki persepsi baik tentang Indonesia dan dapat membangun mutual understanding serta mempengaruhi pola pikir dan tindakan serta kebijakan Amerika. Citra yang ditunjukkan oleh Indonesia dengan diplomasi publiknya adalah Indonesia sebagai negara berbudaya yang moderat, demokratis, dan aman. Indonesia memiliki kebudayaan yang sangat kaya dan menjadi keunikan tersendiri, selain itu dapat dengan mudah diterima oleh publik internasional dan bahkan berasimilasi dengan budaya lain. Contohnya batik is Indonesia, Indonesia berhasil memperkenalkan batik sebagai kekayaan budaya Indonesia dan publik Internasional memberikan apresiasi tinggi dan batik mampu berasimilasi dengan budaya Amerika dimana saat ini telah terselenggara event American batik. Selain itu, Indonesia sebagai negara dengan penduduk muslim terbanyak di dunia menjadi negara contoh dimana demokrasi dan agama dapat berjalan beriringan sehingga stabilitas politik di Indonesia dapat terjaga dengan baik. Indonesia juga mampu menunjukkan prestasi yang baik dalam penanggulangan isu terorisme sehingga Indonesia dapat mengembalikan citranya sebagai negara yang aman.

Kedua, aktivitas diplomasi publik yang dilakukan Indonesia diimplementasikan melalui instrumen-instrumen budaya, pendidikan, official visits dan media sosial dan dilakukan tidak hanya melalui pemerintah ke pemerintah (government to government relations) atau jalur pertama dari diplomasi multi jalur namun juga terakomodirnya seluruh jalur diplomasi yakni dengan menekankan relasi pemerintah dengan masyarakat (government to people relations) dan masyarakat ke masyarakat (people to people contact. Program-program yang dicanangkan melalui instrumen tersebut merupakan hasil kerjasama dari seluruh elemen negara dari pemerintah, stakeholders, diaspora Indonesia dan pihak-pihak individu seperti 
akademisi, pemuka agama dan pelajar/mahasiswa. Secara keseluruhan program yang paling banyak digunakan adalah instrumen budaya. Hal ini dikarenakan Indonesia memiliki kekayaan budaya yang berlimpah dan sangat unik oleh karena itu budaya Indonesia dapat dengan mudah diterima dan dinikmati publik internasional, khususnya Amerika. Ketiga, diplomasi publik yang dilakukan Indonesia berkontribusi dalam pengimplementasian Comprehensive Partnership Agreement Indonesia-United States. Program-program yang dicanangkan dalam Working Groups yang dibawahi oleh Comprehensive Partnership Agreement tersebut dapat diterima dengan baik dan memberikan dampak yang cukup signifikan pada aspek ekonomi, pendidikan dan budaya Indonesia. Hal ini dapat terlihat dari bantuan-bantuan yang berhasil didapatkan oleh Indonesia dalam konteks militer dan bantuan sosial dan kesehatan. Lebih lanjut, diharapkan opini publik yang telah dibangun sebagai hasil dari diplomasi publik Indonesia dapat terjaga dan berpengaruh lebih besar pada kepentingan politik Indonesia dan terutama peran Indonesia dalam kancah Internasional.

Publik domestik Indonesia juga memiliki antusiasme yang baik dalam berperan serta melakukan aktivitas diplomasi publik, hal ini dapat menjadi aset yang sangat baik untuk masa depan diplomasi publik Indonesia. Indonesia dapat menunjukkan konsistensinya sebagai negara demokrasi yang stabil dengan masyarakat yang pluralis dan toleran dan juga pertumbuhan ekonomi yang progresif kepada publik internasional sehingga tercipta citra yang positif yang membantu memberikan kepercayaan dalam melakukan hubungan bilateral dengan Amerika. Namun, yang menjadi kekurangan dari diplomasi publik Indonesia adalah ketidakjelasan dari konseptualisasi definisi dan tujuan diplomasi publik yang ingin dicanangkan oleh Indonesia sehingga praktek diplomasi publiknya masih kurang optimal jika dibandingkan negara-negara lain, khususnya Amerika. Konseptualisasi diplomasi publik Indonesia perlu difokuskan agar pemerintah mampu mengoptimalkan program-program yang mendukung diplomasi publiknya. Indonesia perlu memperjelas "Indonesian Way" seperti apa yang ingin dibentuk dan diperkenalkan pada publik internasional, sehingga tidak hanya citra positif yang 
dicapai namun juga Indonesia dapat dikenal dengan kekhususan tersendiri akan negaranya. 


\section{REFERENSI}

Anholt, S. (2006). "Public Diplomacy and Place Branding: Where's the Link". Journal of Communication Management Vol. 2 (4). Palgrave Mc Millan: New York.

Ciolek, Melani. (2010). Understanding Social Media's Contribution to Public Diplomacy: How Embassy Jakarta's Facebook Outreach Illuminates the Limitations and Potential for the State Department's Use of Social Media. University of Southern California Center on Public Diplomacy: Annenberg School.

Creswell, John W. (2003). Research Design: Qualitative, Quantitative, and Mixed Method Approaches, 2nd ed. Sage Publications: University of Nebraska, Lincoln.

Denmark, A. M, et al. (2010). Crafiting a Strategic Vision: A new Era of USIndonesia Relations. Center for New American Security.

Diamond, Louise \& McDonald, John. (1996). Multi-Track Diplomacy: A System Approach to Peace, $3^{\text {rd }}$ Ed. Kumarian Press: University of Michigan

Direktorat Diplomasi Publik. (2011). Peraturan Menteri Luar Negeri Republik Indonesia Nomor 07 Tahun 2011 Tentang Organisasi Dan Tata Kerja Kementerian Luar Negeri, Bab IX Dirjen Informasi dan Diplomasi Publik. Bag. V, Pasal 680. Kementerian Luar Negeri RI, Direktorat Diplomasi Publik: Jakarta

Direktorat Diplomasi Publik. (2013). Laporan Kongres Diaspora Indonesia. Sumber: Direktorat Diplomasi Publik, Kementerian Luar Negeri Republik Indonesia: Jakarta

Direktorat Diplomasi Publik. (2010). "Presiden RI: Soft Power Memperkuat Formula Diplomasi”. Tabloid Diplomasi No. 28 Tahun III. Direktorat Diplomasi Publik RI: Jakarta.

Djelantik, Sukawarsini. (2008). Trend in Diplomacy; Indonesian Diplomacy Toward Denmark; The Jylland Posten Case. Conference Paper. World International Studies Conference (WISC). Ljubljana University: Ljubljana, Slovenia.

Dung Bui, Anh. (2011). Public Diplomacy in ASEAN and the Cases of Vietnam and Singapore. A Dissertation. Institute of Communication Studies: University of Leeds.

Effendi, Tonny D. (2011). Diplomasi Publik Jepang: Perkembangan dan Tantangan. Ghalia Indonesia: Bogor

(2012). "Strengthening Indonesia-Malaysia Relations by Enhanching Public Diplomacy of Two Countries", proceeding for the 6th Indonesia Malaysia International Conference, Universitas Airlangga-University of Malaya: Surabaya

Gouda, F \& Zaalberg, T. B. (2002). American Visions of the Netherlands East Indies/Indonesia: US Foreign Policy and Indonesian Nationalism 1920-1949. Amsterdam University Press: Amsterdam.

Hiebert, Murray et al. (2013). A US-Indonesia Partnership for 2020: Recommendations for Forging a 21st Century Relationship. Centre for Strategic $\&$ Internastional Studies: Washington. 
International Business Publications USA. (2008). Indonesia Diplomatic Handbook. International Business Publications: Washington. Pg: 26-27

Levy, Jack. S. (2002). "Qualitative Methods in International Relations", in Frank P. Harvey and Michael Brecher (ed.), Evaluating Methodology in International Studies. The University of Michigan Press: Ann Arbor.

Nye Jr, Joseph S. (2004). Soft Power: The Means to Success in World Politics. Public Affairs: New York.

Reid, Anthony. (2012). "Indonesia's New Prominence in the World" in Indonesia Rising: The Repositioning of Asia's Third Giant. Institute of Southeast Asian Studies: Singapore.

Rosenau, James N. (1978). "Restlessness, Change, and Foreign Policy Analysis", in James N. Rosenau, ed., In Search of Global Patterns. New York: Free Press. (1990). Turbulence in World Politics: A Theory of Change and Continuity. Princeton University Press: Princeton.

Smith, Anthony L, (2003). "A Glass Half Full: Indonesia-US Relations in the Age of Terror”, dalam Contemporary Southeast Asia Journal, 25 (3): 449-472.

Sukma, Rizal. (2010). Insight: Strategic Significance of Indonesia-US Relations. The Jakarta Post 10 November 2010.

Tiedeman, Anna. (2005). "Islamic Republic of Iran Broadcasting: Public Diplomacy or Propaganda?." The Fletcher School Online Journal for issues related to Southwest Asia and Islamic Civilization. Spring 2005, Article 5.

Tuch, Hans N. (1990). Communicating With the World. St. Martin's Press: New York.

U.S. Department of State. (1987). Dictionary of International Relations Terms, Washington, D.C.

Suryadinata, Leo. (1996). Indonesia's Foreign Policy Under Soeharto: Aspiring to International Leadership. Times Academic Press: Singapore.

Wolf Jr, Charles \& Rosen, Brian. (2004). Public Diplomacy: How to Think About and Improve It. Rand Corporation. http://www.rand.org/.

Wuryandari, Ganewati. (2008). Politik Luar Negeri Indonesia di Tengah Pusaran Politik Domestik. Pustaka Pelajar: Yogyakarta.

\section{INTERNET}

Atase Perdagangan RI Wahington D.C. (2014). Taste Remarkable Indonesia. Press Release: KBRI Washington D.C

Badan Pusat Statistik. http://www.bps.go.id/. Diakses tanggal 22 Juni 2014

Berita Perwakilan Kementerian Luar Negeri RI. (2013). Kuliah Umum "Interfaith Dialogue in a Plural Society: the View from Indonesia di UC Berkeley. http://www.kemlu.go.id/sanfrancisco/Pages/Embassies.aspx?IDP=110\&l=id. Diakses tanggal 28 April 2014.

Cobb, Kelly. (2012). Batik Diplomacy: Winning Tech-style Design Enriches Indo-US Cultural Exchange. http://www.surfacedesign.org/newsblog/how-a-tech-stylebatik-design-won-me-a-textile-tour-of-java. Diakses tanggal 01 Agustus 2014

Diamond and McDonald. The Institute for Multi-Track Diplomacy (IMTD). (http://www.beyondintractability.org/essay/multi-track-diplomacy). Diakses tanggal 14 September 2014 
Direktorat Diplomasi Publik. (2013). Diplomasi Publik tidak Semata-mata Milik Negara, 09 Oktober 2013. http://www.kemlu.go.id/Pages/NewsKemlu.aspx?IDP=364\&l=id. Diakses tanggal 18 April 2014.

Djalal, Dino P. (2013). Surat Terbuka kepada Diaspora Indonesia di Amerika Serikat. www.embassyofindonesia.org. Diakses tanggal 20 Juli 2014.

Embassy of Indonesia Wahington DC. Bilateral Relations Indonesia-United States. http://www.embassyofindonesia.org/wordpress/?page_id=516. Diakses tanggal 13 Maret 2014.

Embassy of the United States. Belajar di Amerika Serikat. http://indonesian.jakarta.usembassy.gov/studi.html. Diakses tanggal 15 Juli 2014

Hadi, Umar. (2007). Diplomasi Publik Menjembatani Persepsi Domestik dan Internasional. Tabloid Diplomasi Edisi Desember 2007. http://www.tabloiddiplomasi.org/previous-isuue/55-desember-2007/535diplomasi-publik-menjembatani-persepsi-domestik-dan-internasional.html. Diakses tanggal 20 Oktober 2014.

Kompasiana. Diplomasi Publik Indonesia. (2010). http://politik.kompasiana.com/2010/04/21/diplomasi-publik-indonesia-1123493.html. Diakses tanggal 18 April 2014.

Marciel, Scot. (2013). Mempererat Hubungan AS dan RI. Jawa Pos, 04 Juli 2013. http://rumahopini.com/mempererat-hubungan-as-dan-ri/\#ixzz3AToPeBaJ. Diakses tanggal 13 April 2014.

Morse, Jane. (2012). Effective Public Diplomacy Needs Social Media. IIP Digital: US Department of State. http://iipdigital.usembassy.gov/st/english/article/2012/10/20121015137488.html\# axzz35IknCGuf. Diakses tanggal 7 Juni 2014

Napitupulu, Ester. (2014). Gamelan, Orkestra Jawa yang Populer di Amerika. Kompas Online. http://travel.kompas.com/read/2014/01/16/1040553/Gamelan.Orkestra.Jawa.yang. Justru.Populer.di.Amerika. Diakses tanggal 15 Juli 2014

Nugroho, G. (2011). Peran IMF Dalam Penanganan Krisis Ekonomi di Indonesia $1997 / 1998$. http://politik.kompasiana.com/2011/04/05/peran-imf-dalampenanganan-krisis-ekonomi-di-indonesia-19971998-354375.html. Diakses tanggal 12 Februari 2014

Pidato Presiden Soekarno. (1960). “To Build the World a New”. Sidang Umum P B.B. ke-XV tanggal $30 \quad$ September 1960. http://kepustakaanpresiden.pnri.go.id/uploaded_files/pdf/speech/normal/soekarno12.pdf. Diakses tanggal 13 Maret 2014

Pidato Presiden Susilo Bambang Yudhoyono. (2009). Towards Harmony Among Civilizations. John F. Kennedy School Of Government Harvard University: Boston. http://www.presidenri.go.id/index.php/eng/pidato/2009/09/30/1228.html. Diakses Tanggal 29 Agustus 2014.

Rumah Indonesia. http://www.rumah-indonesia.org/the-story.html. Diakses tanggal 22 April 2014. 
Sambutan Presiden Barack Obama seletah rapat bilateral bersama President Susilo Bambang Yudhoyono di Shangri-La Hotel, Singapore, 15 November 2009. http://www.whitehouse.gov/the-press-office/remarks-president-obama-andpresident-yudhoyono-indonesia-after-bilateral-meeting. Diakses tanggal 27 Juni 2014.

Tabloid Diplomasi Edisi Mei. (2013). Indonesia Prakarsai Interfaith Dialogue. http://www.tabloiddiplomasi.org/current-issue/189-diplomasi-mei-2013/1672indonesia-prakarsai-interfaith-dialogue.html. Diakses tanggal 18 Mei 2014.

Tabloid Diplomasi Edisi September. (2011). Presidential Friends of Indonesia (PFoI). http://www.tabloiddiplomasi.org/previous-isuue/159-september-2011/1219presidential-friends-of-indonesia-pfoi-2011-09-19.html. Diakses tanggal $18 \mathrm{Mei}$ 2014.

United States Department of State. (2014). Country Reports on Terrorism. Bureau of Counterterrorism. http://www.state.gov/j/ct/rls/crt/index.htm. Diakses tanggal 8 Agustus 2014.

United States Information Agency Alumni Association, "What Is Public Diplomacy? http://pdaa.publicdiplomacy.org/?page_id=6. Diakses tanggal 16 Oktober 2014

US Department of State. (2010). United States - Indonesia Comprehensive Partnership. Fact Sheet. http://www.state.gov/r/pa/prs/ps/2013/10/215196.htm. Diakses tanggal 13 Maret 2014.

Website Resmi Presiden Republik Indonesia. (2010). Pidato Sambutan Presiden Susilo Bambang Yudhoyono pada Jamuan Makan Malam Kenegaraan bersama Presiden Amerika Serikat Barack Husein Obama. Istana Negara, 9 november 2010. Http://www.presidenri.go.id/index.php/pidato/2010/11/09/1517.html. Diakses tanggal 13 Maret 2014.

World Bank Data. (2013). United States of America - Indonesia Comparison Data. http://databanksearch.worldbank.org/DataSearch/LoadChart.aspx?db=2\&cntrycod $\mathrm{e}=\mathrm{USA}$,IDN\&sercode $=\&$ yrcode=\#. Diakses tanggal 20 Oktober 2014

Zhida, Jiang. (2012). Indonesia's "Confidence" Diplomacy under the Yudhoyono Government. China Institute of International Studies. http://www.ciis.org.cn/english/2012-12/31/content_5638110.htm. Diakses tanggal 19 Agustus 2014.

\section{WEBSITE}

American Batik Design Competition. http://americanbatik.embassyofindonesia.org/. Diaspora Indonesia. http://www.diasporaindonesia.org/

Kedutaan Besar Indonesia, Washington D.C. http://www.embassyofindonesia.org/wordpress/

Presiden Republik Indonesia. http://www.presidenri.go.id/

\section{WAWANCARA}

Bapak Restu, Ketua Sub-bidang Diplomasi Budaya. Direktorat Diplomasi Budaya. Direktorat Jenderal Internalisasi dan Diplomasi Budaya. Kementerian Pendidikan dan Kebudayaan RI. Tanggal 21 April 2014. 
Bapak Siuaji Raja, Staf Direktorat Diplomasi Publik, Direktorat Jenderal Informasi dan Diplomasi Publik, Kementerian Luar Negeri RI. Tanggal 5 Mei 2014.

Ibu Angela. Staf Direktorat Amerika Utara dan Tengah. Direktorat Jenderal Amerika dan Eropa, Kementerian Luar Negeri RI. Tanggal 7 Mei 2014.

Bapak Mulyanto Sastrowiranu, Staf Direktorat Diplomasi Publik. Direktorat Jenderal Informasi dan Diplomasi Publik, Kementerian Luar Negeri RI. Tanggal $21 \mathrm{Mei}$ 2014.

Tonny Dian Effendi, Dosen Hubungan Internasional Universitas Muhammadiyah Malang. Penulis Buku Diplomasi Publik Jepang: Perkembangan dan Tantangan. Tanggal 23 Mei 2014. 